\title{
AGRONOMIC EVALUATION OF SUNFLOWER CULTIVARS ADAPTED TO NORTHERN FLUMINENSE CONDITIONS AND GROWN FOR BIOMASS PRODUCTION
}

\author{
Avelino dos Santos Rocha ${ }^{1}$, Camila Queiroz da Silva Sanfim de Sant'Anna², \\ Geovana Cremonini Entringer ${ }^{3}$, Rogério Figueredo Daher ${ }^{4}$, \\ Geraldo de Amaral Gravina ${ }^{4}$, Ziraldo Moremos dos Santos ${ }^{5}$
}

\begin{abstract}
${ }^{I}$ Engenheiro Agrônomo. Mestre em Produção Vegetal - UENF.
${ }^{2}$ Engenheira Agrônoma. Mestre em Genética e Melhoramento Vegetal-UENF.

${ }^{3}$ Engenheira Agrônoma. Doutora em Genética e Melhoramento Vegetal UENF.

${ }^{4}$ Engenheiro Agrônomo. Professor Associado da UENF.

${ }^{5}$ Engenheiro Agrônomo. Doutor em Produção Vegetal - UENF.
\end{abstract}

Corresponding author: Geovana Cremonini Entringer (geovanaentringer@gmail.com).

\begin{abstract}
The growing interest in oil seeds in Brazil, mainly in sunflower, was boosted by the introduction of biodiesel in the market, and by the species excellent physical-chemical and nutritional characteristics, which intensified the search for more productive cultivars adapted to specific cultivation regions. The aim of the present study is to feature and assess five sunflower varieties (BRS 321, Embrapa 122, Helio 253, Multissoland Uguara 04) in order to find the best varieties to the Northern Fluminense region. The experiment was conducted at PESAGRO-RIO Experimental Station, which is located in Campos dos Goytacazes County, Rio de Janeiro State. Grain phenological, morphological and yield characteristics were assessed. The $\mathrm{F}$ test at $1 \%$ significance level showed significant effect between varieties. Variety Helio 253 stood out as the most adapted to the soil and climatic conditions in the region. It was the most productive variety; 3,285.2 kg.ha-1 on average. Such outcome is correlated to its low plant height $(1.24 \mathrm{~m})$. This feature is favorable for the high incidence of wind in the regions, since it avoids damages to the stem and plant lodging.
\end{abstract}

Keywords: Sunflower, agronomics traits, biomass productions

\section{Introduction}

Sunflower (Helianthus annuus L.) is an annual oilseed currently grown in all continents due to its rusticity. It is capable of adapting to different latitudes, longitudes and photoperiods, besides being an option for rotation and succession cultures in grain-producer regions, and for exhausted and unproductive regions, as well as a green fertilization option (Pereira et al., 2014).

The first studies related to sunflower oil extraction in Brazil were conducted in Ceará State back in 1979, the so called Prodiesel (Alves et al., 2004). Biodiesel consists of all fuel types produced from renewable sources, such as animal fat and vegetal oils. These fuels are obtained through transesterification of grease with short-chain alcohols such as methanol and ethanol, in presence of acid or basic catalysts (Ahmia et al., 2014; Pereira et al., 2014; Marulanda-Buitragoand Marulanda-Cardona, 2015).

The search for alternatives focused on environmental and socioeconomic aspects is getting more worrisome, mainly because of the great concern with the negative effect of gas and particle emissions on human health. These alternatives must be capable of reducing greenhouse effects and be sustainable (Rêgo Filho et al., 2005).

Previous research has already shown that sunflower cultivation can be practiced country wide in Brazil, depending on the specificities of each region, such as: the time to sow the cultivar of choice, among others (Castro and Farias, 2005; Dalchiavon et al., 2016). 
Sunflower cultivars were here in assessed in order to find the most adapted cultivar to the soil and climatic conditions in the Northern Fluminense region. Such study becomes essential given the current lack of technical and scientific information about the cultivation and management of sunflower crops in Rio de Janeiro State.

\section{Materials and methods}

\section{Experimental site}

The experiment was installed at PESAGRORIO experimental Station, in Campos dos Goytacazes County, Rio de Janeiro State, at geographic coordinates $21^{\circ} 45^{\prime}$ 'South latitude and $41^{\circ} 18^{\prime}$ 'West longitude, altitude $11 \mathrm{~m}$. The site is composed of Cambissolo.

According to the Köppens' classification, the climate in the region is of the Aw type: hot and humid. The mean annual temperature is approximately $23.2^{\circ} \mathrm{C}$, mean maximum temperature $29^{\circ} \mathrm{C}$ and mean minimum temperature $19^{\circ} \mathrm{C}$. The region is featured by its mean annual rainfall $(884.8 \mathrm{~m})$ and main rainfall concentration from October to March.

Soil samples were collected 0 to $20 \mathrm{~cm}$ from soil surface, before experiment implementation, in order to analyze its fertility based on the Manual for the $5^{\text {th }}$ approach to the use of Correctives and Fertilizer/MG (Ribeiro et al., 1999). This manual is used to calculate the necessary fertilizations and corrections.

\section{Cultivars}

Five sunflower genotypes were used in the experiment, three simple hybrids, and two open pollinated varieties:

AGUARA 4: simple hybrid, black achenes with grey stretch marks, early cycle, flowering between 55 and 65 days, convex-shape sessile flower, plant height 1.5 to $1.8 \mathrm{~m}$, high oil content (Atlântica Sementes).

Embrapa 122: early cycle variety (100 days) and high oil content, mean yield 1,700 kg.ha ${ }^{-1}$ and oil content $41.50 \%$. It presents limitations to mechanic harvesting due to its lack of uniformity in plant height and in the cycle (EMBRAPA).

Embrapa BRS 321: simple hybrid launched in 2011, early cycle (90 days); excellent uniformity, fact that facilitates harvesting; resistant to mildew, mean yield higher than 2,000 kg.ha-1 and approximate mean oil content $42 \%$, besides good adaptation to the entire national territory (EMBRAPA).

Helio 253: simple hybrid, black achenes, early cycle (100 days), excellent self-compatibility, great resistance to lodging, mean plant height $1.40 \mathrm{~m}$, mean yield higher than 2,000 kg.ha-1 and approximate oil content 45\% (Helianthus do Brasil LTDA).
Multissol: open pollinated variety, black achenes (which can also be black with grey or white stretch marks, up to $5 \%$ ), mean cycle 105 days, mean height $1.65 \mathrm{~m}$, mean yield $1,800 \mathrm{~kg} \cdot \mathrm{ha}^{-1}$ and mean oil content $43 \%$ (CATI).

\section{Experimental design}

The study followed the completely randomized block design, and total of $486 \mathrm{~m}^{2}(27 \mathrm{~m} \times 18 \mathrm{~m})$, with four blocks and five plots. Each block comprised five plots $(6 \mathrm{~m} \times 3.6 \mathrm{~m})$ with four rows $(6.0 \mathrm{~m})$ with $0.9 \mathrm{~m}$ spacing between lines and $0.45 \mathrm{~m}$ pacing between side tips. Density was five plants per linear meter. Evaluations were conducted in the two central rows of each plot, $1 \mathrm{~m}$ of each row tip was discarded. The useful area of each plot recorded $7.2 \mathrm{~m}^{2}(4 \mathrm{~m} \times 1.8 \mathrm{~m})$.

\section{Sowing, culture management and harvest}

Soil was firstly prepared by using plowing tractor and plow leveler a week later. Fertilization was distributed and manually added with $300 \mathrm{~kg} \cdot \mathrm{ha}^{-1}$ of the formula 04-14-08, with boron addition in the planting grooves. The grooves were mechanically prepared (7 $\mathrm{cm}$ deep). Sowing was manually performed $3 \mathrm{~cm}$ down in the groove; ten seeds per linear meter.

Complete germination was recorded 10 days after sowing, trimming was performed 10 days after germination, approximately five plants were left per linear meter. Weed control was performed through manual weeding, 10 and 15 days after trimming.

Irrigation was achieved through sprinkler irrigation, by applying a $20 \mathrm{~mm}$ water blade in order to allow culture development, mainly in the first month, when there was no rainfall. It assured uniform plantlet emergence.

The harvest conducted for achene assessment purposes was performed at the two central rows when the plants had already presented physiological maturation. It was done by using pruning shears. The basis of the sessile flower was cut in order to be exposed to the sun. The sessile flower was turned upside down and left to completely dry before the grains. The grains were manually trod and the obtained achenes were once more exposed to the sun until they reached $11 \%$ humidity in order to be stored and assessed.

\section{Assessed varieties}

The assessed characteristics were evaluated in the ten plants from the useful fraction of each of the randomly chosen plots:

- Plant height $(\mathrm{cm})-\mathrm{PH}$ : Measured from soil surface to sessile flower insertion. Measurements were taken with a calibrated wooden ruler during the complete flowering period; 
- Lower stem diameter $(\mathrm{mm}) 5 \mathrm{~cm}$ from soil surface - LSD: The measurements were taken with a caliper during the complete flowering period;

- Upper stem diameter $(\mathrm{mm}), 5 \mathrm{~cm}$ below the sessile flower projection - USD: Measurements were taken with a caliper during the complete flowering period;

- Sessile flower diameter $(\mathrm{cm})$, based on the diameter of the inflorescence receptacle - SFD: Measurements were taken with a calibrated ruler during the physiological maturation period;

- Sessile flower weight (g) - SFW: based on the sessile flower yield of the ten randomly selected plants from each plot and on their further weighing on high precision scale;

- Achene weight $(\mathrm{g})$ - AW: Based on the grain yield of the ten randomly selected plants from each plot and by further grain weighing on high-precision scale;

- Plant of germination - PG: Period at the beginning of the flower bud (days) was recorded when $50 \%$ of the plants from the plot presented flower bud formation;

- Germination period at complete flowering (days) - FG: Recorded when $50 \%$ of the plants from the useful fraction of the plot presented open sessile flowers; and

- Plant cycle (days) - PC: Recorded when $90 \%$ of the plants from the useful fraction of the plot presented sessile flowers with yellow and brown bracts.

\section{Statistical analysis}

The analysis of variance was performed through the $\mathrm{F}$ test at $1 \%$ probability level using one co-variable: number of plants. It was done to correct the favoring of some plants due to flaws in some plots. The Tukey test at 5\% probability level was followed by the test of means in the SISVAR software (Ferreira, 2011).

\section{Results And Discussion}

The significant effect of the variety was found through the $\mathrm{F}$ test at $1 \%$ significance level (Table 1 ). There was difference between all the assessed varieties.

The total cycle of the cultivars (Table 2) recorded 101.2 days, on average. It lasted 43.4 and 62 days for flowering and complete flowering, on average, respectively.

EMBRAPA (2007) recorded 95.0 days for the total cycle and 57.4 for complete flowering, on average. Backes et al. (2008) evaluated twelve sunflower genotypes in two different planting periods and found that January recorded 97.3 days, on average; 60.5 days for the total cycle and for the complete flowering, respectively. February planting recorded 107.3 days, on average; 68.8 days for the total cycle and for complete flowering, respectively. Lustri et al. (2017) highlights that the distinction between genotype results concerns the different cultivation environments, and that it influences the selection of the genotype best adapting to such cultivation region.

Values in the current study meet those of other research performed at national scope during different planting periods, because they reflect the high mean temperatures in the Northern Fluminense region, which allow culture implementation.

\section{Morphological features analysis}

Table 3 shows the results of the morphological features of the assessed sunflower varieties.

The mean height of the varieties was $1.29 \mathrm{~m}$, and the heights differed from each other at $5 \%$ significance level. Such result was a little below the average recorded in trials conducted by EMBRAPA (2007), which found $160.77 \mathrm{~cm}$. However, this variable does not directly influence achene production, since Helio 253 was the variety recording the best achene production and the lowest mean plant height $(1.24 \mathrm{~m})$. This variety also favors manual harvest and prevents tipping and lodging.

There was correction between the mean upper and lower stem diameter. The lower diameter of each cultivar was used for comparison purposes. These diameter measurements statistically differed from each other at 5\% significance level, and Helio 253 stood out among the other varieties in this particular variable. Ribas (2009) did not find any difference between the tested cultivars and the summer trial conducted by Backes et al. (2008), who recorded mean lower diameter $2.53 \mathrm{~cm}$.

The yield of the sampled plants was estimated based on yield per hectare, depending on the achene weight of the ten plants from the experimental plot (Table 4) of each cultivar. Spacing between rows was set in $0.9 \mathrm{~m}$ and spacing between plants was 0.2 , thus totaling 55,500 plants $\mathrm{ha}^{-1}$. Yield was determined: BRS 321, 2,302.14 kg.ha' ${ }^{-1}$; Embrapa 122, 1,640.80 kg.ha-1; Helio 253,3,285.21 kg.ha-1 ; Multissol, 2,250.03 kg.ha- ${ }^{-1}$; Uguara 4, 1,862 kg.ha- ${ }^{-1}$. Cultivars also differed from each otherin this characteristic through the Tukey test at $5 \%$ significance level. Helio 253 stood out due to its estimated yield, which was more than three tons ha ${ }^{-1}$. This value overpasses the expectations of national mean yield $\left(1,255 \mathrm{~kg} \mathrm{ha}^{-1}\right)$ for the 2012/13 crop (CONAB 2012). According to Backes et al. (2008), who assessed the performance of twelve sunflower genotypes in two different times, sunflower yield is satisfactory when it is higher than $1,800 \mathrm{~kg} \cdot \mathrm{ha}^{-1}$. All the varieties in the present study recorded higher values than this one, except for Embrapa $122\left(1,640.80 \mathrm{~kg} \cdot \mathrm{ha}^{-1}\right)$. 
Productivity is directly proportional to the mean stem and sessile flower diameters. The means of the largest stem diameters tend to be higher for the sessile flower diameter, whereas plants presenting larger sessile flower diameter also present higher achene production. These characteristics are of great interest for the biodiesel production industry.

Table 1. Summary of the analysis of variance of the morphological parameters of five varieties of sunflower. Campos dos Goytacazes-RJ, March of 2012.

\begin{tabular}{lccccccc}
\hline SV & DF & SFW & AW & PH & LSD & USD & SFD \\
\hline Block & 3 & 35458.3 & 1115.13 & 37.81 & 0.35 & 0.15 & 38.62 \\
Genotype & 4 & $104.67 * *$ & $51728.29^{* *}$ & $35.11^{* *}$ & $5.72 * *$ & $4.11^{* *}$ & $266.93^{* *}$ \\
Linear plant & - & & - & 3.42 & 0.01 & 0.21 & 10,40 \\
Residue & 12 & 121188 & 8709.68 & 2.55 & 0.16 & 0.11 & 6.03 \\
CV (\%) & & 24.39 & 22.84 & 12.36 & 18.06 & 24.3 & 15.68 \\
\hline
\end{tabular}

** Significant at 0.01 level probability by the F test. SFD - Sessile flower diameter $(\mathrm{cm})$, based on the diameter of the inflorescence receptacle; AW - Achene weight (g); PH - Plant height (cm); LSD - Lower stem diameter (mm) $5 \mathrm{~cm}$ from soil surface; USD - Upper stem diameter (mm), $5 \mathrm{~cm}$ below the sessile flower projection; SFD - Sessile flower diameter $(\mathrm{cm})$, based on the diameter of the inflorescence receptacle

Table 2. Phenological characters of five varieties of sunflower (Helianthus annuus L.). Campos dos Goytacazes-RJ, March of 2012.

\begin{tabular}{cccc}
\hline Genotype & FG & PG & PC \\
\hline BRS 321 & 40 & 61 & 101 \\
Embrapa 122 & 45 & 59 & 98 \\
Hélio 253 & 47 & 65 & 105 \\
Multissol & 41 & 62 & 100 \\
Uguará 4 & 44 & 63 & 102 \\
Mean & 43.4 & 62 & 101 \\
\hline
\end{tabular}

FG - Germination period at complete flowering (days); PG - Plant of germination (days); PC- Plant cycle (days).

Table 3. Morphological characters of five varieties of sunflower (Helianthus annuus L.) Campos dos Goytacazes-RJ, March 2012.

\begin{tabular}{ccccc}
\hline Genotype & PH & LSD & USD & SFD \\
\hline BRS 321 & $1.17 \mathrm{~d}$ & $2.03 \mathrm{c} \mathrm{d}$ & $1.26 \mathrm{~b}$ & $14.98 \mathrm{~b}$ \\
Embrapa 122 & $1.28 \mathrm{bc}$ & $1.83 \mathrm{~d}$ & $1.02 \mathrm{c}$ & $13.93 \mathrm{~b}$ \\
Hélio 253 & $1.24 \mathrm{~cd}$ & $2.84 \mathrm{a}$ & $1.88 \mathrm{a}$ & $20.15 \mathrm{a}$ \\
Multissol & $1.36 \mathrm{ab}$ & $2.16 \mathrm{~b} \mathrm{c}$ & $1.24 \mathrm{~b}$ & $15.30 \mathrm{~b}$ \\
Uguará 4 & $1.40 \mathrm{a}$ & $2.28 \mathrm{~b}$ & $1.31 \mathrm{~b}$ & $13.95 \mathrm{~b}$ \\
\hline Mean & 1.29 & 2.23 & 1.34 & 15.66 \\
\hline
\end{tabular}

Means followed by the same letter do not differ significantly by the Tukey test at 0.05 level probability. PH - Plant height (cm); LSD - Lower stem diameter $(\mathrm{mm}) 5 \mathrm{~cm}$ from soil surface; USD - Upper stem diameter $(\mathrm{mm}), 5 \mathrm{~cm}$ below the sessile flower projection; SFD - Sessile flower diameter $(\mathrm{cm})$, based on the diameter of the inflorescence receptacle. 
Table 4. Yield and characterization of achene of five varieties of sunflower (Helianthus annus L.). Campos dos Goytacazes, March 2012.

\begin{tabular}{ccc}
\hline Genotype & Sessile flower weight $(\mathrm{g})$ of 10 plants & Achene weight $(\mathrm{g})$ of 10 plants \\
\hline BRS 321 & $1062.50 \mathrm{~b}$ & $414.80 \mathrm{ab}$ \\
Embrapa 122 & $1175.00 \mathrm{~b}$ & $295.64 \mathrm{~b}$ \\
Helio 253 & $2325.00 \mathrm{a}$ & $591.93 \mathrm{a}$ \\
Multissol & $1337.50 \mathrm{~b}$ & $405.41 \mathrm{ab}$ \\
Uguará 4 & $1237.50 \mathrm{~b}$ & $335.64 \mathrm{~b}$ \\
\hline Mean & 1427.5 & 408.68 \\
\hline
\end{tabular}

Means followed by the same letter do not differ significantly by the Tukey test at 0.05 level probability.

\section{Conclusions}

Among all tested and assessed varieties, Helio 253 was the most productive and adapted variety to the soil and climate conditions in the region. It recorded estimated mean yield 3,285.21 kg.ha-1.

Sunflower is a promising culture for the region, mainly, as raw material for biodiesel production, if one takes into account the petrochemical potential of the region.

\section{Acknowledgments}

The authors want to thank the National Council for Scientific and Technological Development (CNPq) and the Rio de Janeiro Research Foundation (FAPERJ).

\section{References}

AHMIA, A.C.; DANANE, F.; BESSAH, F.; BOUMESBAH, I. 2014. Raw material for biodiesel production. Valorization of used edible oil. Revue des Energies Renouvelables, 17(2):335-343.

AlVES, M.O.; SOBRINHO, J.N.; CARVALHO, J.M.M. 2004. Possibilidade de mamona como fonte de matéria-prima para a produção de biodiesel no Nordeste brasileiro, Banco do Nordeste do Brasil S.A. Fortaleza, 41p.

BACKES, R.L.; SOUZA, A.M.; BALBINOT JÚNIOR, A.A.; GALLOTTI, G.J.M.; BAVARESO, A. 2008. Desempenho de cultivares de girassol em duas épocas de plantio de safrinha no planalto norte catarinense. Scientia Agraria, 9(1):41-48.

CASTRO, C.; FARIAS, J.R.B. 2005. Ecofisiologia do girassol. In: Leite, R.M.V.B. de C.; Brighenti, A.M.; Castro, C. de. Girassol no Brasil, EMBRAPA- CNPSo, Londrina. 163:218.

CONAB - CONSELHO NACIONAL DE ABASTECIMENTO. 2012. Safras 2012/2013: 13 $^{\circ}$ levantamento. Acessed in: 15 de maio de 2019. Disponible in: https://www.conab.gov.br/

DALCHIAVON, F.C.; CARVALHO, C.G.P.; AMABILE, R.F.; GODINHO, V.P.C.; RAMOS, N.P.; ANSELMO, J.L. 2016. Características agronômicas e suas correlações em híbridos de girassol adaptados à segunda safra. Pesquisa Agropecuária Brasileira, 51(11):1806-1812.

EMBRAPA. 2007. Informes da avaliação de genótipos de girassol 2005/2006 e 2006, EMBRAPA Soja, Londrina. $120 \mathrm{p}$.

FERREIRA, D.F. 2011. Sisvar: um sistema computacional de análise estatística. Ciência e Agrotecnologia, 35(6):1039-1042.

LUTRI, E.A.; SILVA, B.T.; PERUCHI, D.R.E.; MOURA, I.A.; FLUMINHAN, A. 2017. Avaliação do desempenho agronômico de cultivares de girassol (Helianthus annuus L.) no cultivo em safrinha na região Oeste Paulista. Periódico eletrônico Fórum Ambiental da Alta Paulista, 13(1):37-51. 
MARULANDA-BUITRAGO, P.; MARULANDA-CARDONA, V. 2015. Supercritical Transesterification of Beef Tallow For Biodiesel Production In A Batch Reactor. Ciencia Tecnología y Futuro, 6(2):57-68.

PEREIRA, T.A.; SOUTO, L.S.; SÁ, F.V.S.; PAIVA, E.P.; SOUZA, D.L.; SILVA, V.N.; SOUZA, F.M. 2014. Esterco ovino como fonte orgânica alternativa para o cultivo do girassol no semiárido. Revista Agropecuária Científica no Semi-Árido, 10(1):59-64.

RÊGO FILHO, L.M.; OLIVEIRA, L.A.A.; ANDRADE, W.E.B. 2005. Mamona e girassol como matéria-prima para produção de biodiesel na região Norte Fluminense: Primeiros resultados. In: Anais II Congresso Brasileiro de Plantas Oleaginosas, Óleos, Gorduras e Biodiesel. Universidade Federal de Larvas, Varginha, 251:255.

RIBEIRO, A.C.; GUIMARÃES, P.T.G.; ALVAREZ, V.H. 1999. Recomendações para o uso de corretivos e fertilizantes em Minas Gerais. Comissão de Fertilidade do Solo do Estado de Minas Gerais CFSEMG, Viçosa. 359p. 